\title{
A invenção do Brasil como terra do samba: os sambistas e sua afirmação social ${ }^{1}$
}

Adalberto PARANHOS

RESU Mo: Como numa corrida de obstáculos, o samba percorreu caminhos acidentados até ser reconhecido pelas instâncias de legitimação do Estado como símbolo nacional. Nesse processo os compositores e intérpretes do samba urbano carioca jogarão um papel decisivo. Este artigo busca aclarar alguns aspectos pouco estudados das marchas e contramarchas que assinalaram a história do samba e sua passagem da condição de artefato cultural marginal à de portador da singularidade brasileira no campo musical.

PALAVRAS-CHAVE: samba; música popular brasileira; símbolos nacionais.

0 samba, a prontidão e outras bossas

São nossas coisas, são coisas nossas!

Noel Rosa

Na galeria de ícones nacionais, a invenção social do Brasil como terra do samba representa uma imagem que perdura até os dias de hoje, atravessando os tempos apesar de todos os contratempos no terreno da música popular brasileira. Denominador comum da propalada identidade cultural brasileira no segmento da música, o samba urbano teve que enfrentar um longo e acidentado percurso até deixar de ser um artefato cultural marginal e receber as honras da sua consagração como símbolo nacional. Essa história, cujo ponto de partida pode ser recuado até a virada dos séculos XIX eXX, foi toda ela permeada por idas e vindas, marchas e contramarchas, descrevendo, dial eticamente uma trajetória que desconhece qualquer traçado uniforme ou linear. 
Os caminhos trilhados pelo samba - mais especificamente pelo "samba carioca" - estão conectados ao contexto mais geral do desenvolvimento industrial capital ista. Embora me dispense de abordar aqui, em detalhes, as transformações que estavam em andamento, aponto, de passagem, al gumas mudanças fundamentais que levaram o samba - mesmo sem perder contato com suas raízes negras - a incorporar outras atitudes e outros tons. Como música popular industrializada, sua expansão girou, e nem poderia ser diferente, na órbita do crescimento da indústria de entretenimento ou, como queira, da indústria cultural. Para tanto jogaram um papel decisivo a própria urbanização e a diversificação social experimentada pelo Brasil nas primeiras décadas do século XX.

Interligada a essas transformações, a música popular, tornada produto comercial de consumo de massa, revelará a sua face de mercadoria. Pelo menos quatro fatores básicos, a meu ver, convergirão no sentido de favorecer esse processo que atingirá em cheio o samba: a) originalmente, bem cultural socializado, isto é, de produção e fruição coletivas, com propósitos lúdicos e/ ou religiosos, o samba alcança também o estágio de produção e apropriação individualizadas, com fins comerciais; b) ancorada nos dispositivos elétricos de gravação, a indústria fonográfica, com suas bases sediadas no Rio de Janeiro, avança tecnologicamente em larga escala e conquista progressivamente consumidores de setores médios e de al ta renda; c) o autoproclamado rádio educativo cede passagem, num curto lapso de tempo, ao rádio comercial, que adquire o status de principal plataforma de lançamento da música popular, deixando para trás os picadeiros dos circos e os palcos do teatro de revista; d) a produção e a divulgação do samba, num primeiro momento praticamente restritas às classes populares e a uma população com predominância de negros e/ ou mulatos, passam a ser igualmente assumidas por compositores e intérpretes brancos de classe média, com mais fácil acesso ao mundo do rádio e do disco.

$\mathrm{N}$ ão constitui novidade alguma falar sobre a conversão de símbolos étnicos em símbolos nacionais, inclusive no caso do samba. Uma extensa bibliografia já se ocupou do assunto, ${ }^{3}$ e não pretendo repisar, a todo instante, fatos e argumentos ao alcance de todos. 0 que me pro- 
ponho fazer neste artigo consiste simplesmente em destacar apenas mais um ângulo de visão do mesmo tema, por entender que, em geral, ele não foi suficientemente explorado. Por outras palavras, sem pretensões a um trabalho de caráter musicológico, disponho-me a examinar um aspecto particular: o discurso musical de compositores e intérpretes da música popular brasileira industrializada, entre o final dos anos 20 e meados dos 40 do século XX, período que cobre desde o surgimento do "samba carioca" até sua consolidação como expressão musical de brasilidade.

Buscarei, por conseqüência, privilegiar os registros sonoros - a produção fonográfica - como corpo documental. Tomando como referência a au dição das gravações da época, trata-se de evidenciar como, no campo de forças que se delineia na área da criação musi cal , 0 samba vai sendo inventado como elemento essencial da singularidade cultural brasileira por obra dos próprios sambistas. O bviamente não se deve ignorar a presença em cena de outros sujeitos sociais engajados nesse movimento de fabricação/invenção dessa tradição. No entanto, irei me concentrar no papel desempenhado pelos produtores/divulgadores do samba como protagonistas de uma história cujo enredo não foi ditado tão-somente pela ação das elites e/ou do Estado.

À medida que o Estado entra em campo para empreender uma operação simultânea de institucionalização e/ou ressignificação do samba - notadamente sob o "Estado N ovo" - , ele atuará de modo seletivo na perspectiva de aproximar o samba dos seus projetos político-ideológicos, e de apartá-lo daquilo que era tido e havido como dissonante em relação ao ideário do governo Vargas. Esbarrando em limitações de espaço, não poderei, neste trabalho, deter-me na análise da ação estatal. Q uero, desde já, entretanto, frisar que este texto está em sintonia com as críticas que, não é de hoje, se vêm formulando às tendências historiográficas que erigem o Estado como "o grande sujeito" ou o sujeito demiúrgico que faz a história, relegando os demais atores à condição de meros coadjuvantes, quando não de massa carente devoz própria. ${ }^{4}$

Gostaria de lembrar ainda que a ação estatal, por não ser única nem uniforme, aparece em meio a tensões permanentes que envolve- 
ram esse processo de legitimação do samba. Tensões presentes quer na trincheira da produção musical brasileira, quer no interior das classes dominantes e elites intelectuais, quer entre integrantes do próprio aparelho de Estado. Tensões, aliás, que se estenderão inclusive às relações entre a música popular eo "Estado Novo", que alimentou um dia a ilusão da criação do coro da unanimidade nacional.

\section{SALVE O PRAZER: O SAMBA COMO PRODUTO NACIONAL}

Nos últimos anos da década de 20 do século passado, um terremoto de efeito prolongado abalou, de al to a baixo, a música popular brasileira. Seu epicentro foi o bairro de Estácio de Sá, encravado entre o M orro de São Carlos e o M angue, nas proximidades da zona central do Rio de Janeiro. Reduto de gente pobre, com grande contingente de pretos e mulatos, era um prato cheio para as associações que normalmente se estabelecem entre classes pobres e "classes perigosas". Daí viverem cercados de especial atenção por parte da polícia.

Berço do novo samba urbano, o Estácio não terá, todavia, exclusividade no seu desenvolvimento. Quase simultaneamente, o "samba carioca", nascido na "cidade", iria gal gar as encostas dos morros e se alastrar pela periferia afora, a ponto de, com o tempo, ser identificado como "samba de morro". Até impor-se como tal e, mais, como ícone nacional, uma batalha, ora estridente, ora surda, teve que ser travada. Estava-se diante daquilo que Roger Chartier designa como “lutas de representações" ${ }^{5}$. Tornava-se necessário remover resistências até no próprio campo de produção do samba, das gravadoras e dos hábitos musicais dos maestros.

Para alguns, o novo samba urbano em gestação representaria, na verdade, uma deturpação do samba. Sinhô, D onga e outros mais cerravam fileiras contra a modali dade de samba à la Estácio $\&$ cia. Figuras proeminentes da primeira geração de fundadores do samba urbano baiano-carioca, eles não se conformavam com o estilo que arrebanhava mais e mais adeptos. Em vez da sua feição amaxixada, emergia um samba que, sem deixar de ser batucado, assumia uma ca- 
racterística de música mais marchada, como decorrência da aceleração rítmica, considerada mais apropriada para os desfiles de carnaval.

Para quem fora educado na tradição do samba amaxixado - a chula raiada ou samba raiado ou, tanto faz, o samba de partido-alto - , os "modernistas" estavam indo longe demais. ${ }^{6}$ Em tempos de expansão da indústria fonográfica e da mercadoria disco, outras mudanças se processavam, contribuindo para maior adequação da música gravada às novas realidades. Com o samba do Estácio ocorria, por exemplo, a valorização da(s) segunda(s) parte(s) da música e letra das composições. Em lugar da improvisão costumeira das rodas de samba de partido-alto - apoiado numa célula-mãe, o estribilho, com base no qual corriam soltos os versos improvisados - tinham-se agora seqüências preestabelecidas, com unidade temática e possibilidade de se encaixar tudo no tempo médio das gravações de 78 rpm, que girava ao redor de três minutos.

Deinício nem as gravadorasnem os maestros conseguiram apreender muito bem o significado dessa ebulição na área do samba. Para provar isto basta um exercício comparativo que ponha frente a frente quatro gravações de sambas típicos da safra do Estácio. De um lado, N ovo amor (delsmael Silva), com M ário Reise acompanhamento da O rquestra Pan-American, regida pelo russo Simon Bountman, de 1929, e Se vocêjurar (de Ismael Silva, Nilton Bastos e Francisco Alves), com Mário Reise O rquestra Copacabana, de 1930. De outro lado, Adeus (de Ismael Silva, N oel Rosa eFrancisco Alves) , com Jonjoca eCastro Barbosa, acompanhados pelo Grupo da Guarda Velha, de 1932, eAgora é cinza (deBide e M arçal) , com M ário Reis e Diabos do Céu, de 1933. No primeiro caso, a combinação rítmico-sonora é marcada por uma orquestração amaxixada, que pouco tinha a ver com a concepção que inspirara os compositores do Estácio. Essa constatação nos adverte quanto aos nexos existentes entre percepção e experiência, ou ainda quanto à historicidade da percepção. Não sendo a partitura um fato em si, dotado de sentido unívoco, o próprio olhar e/ou a própria leitura éinterpretação. Por isso, nessa linha de raciocínio, Gombrich ressalta o peso dos “hábitos conceituais" ou de uma schemata, em função dos quais "pedir um olhar (ou um ouvir, acrescento eu) inocenteé pedir o impossível".7 
Afastando-se dos hábitos musicais que ficavam reféns de uma lógica tradicional, Pixinguinha, regente e orquestrador, líder do Grupo da Guarda Velha e dos Diabos do Céu, ajustava seus passos e seus compassos à situação musical emergente. Não é à toa que acabou por ser enaltecido como o inventor da linguagem orquestral brasileira. Ele que dera um salto que o projetou à frente de si mesmo, como se percebe ao ouvi-lo, anos antes (1929), conduzindo à moda antiga a O rquestra Típica Pixinguinha-D onga, no registro do samba de sua autoria Gavião calçudo, interpretado por Patrício Teixeira.

$\mathrm{Na}$ corrida do samba para afirmar-se como produto nacional, era preciso saltar outros obstáculos dispostos pelo caminho. Ao enfocar aqui a área da produção musical, chamo a atenção para a necessidade do samba incorporar outros grupos e classes sociais, promovendo assim um deslocamento relativo de suas fronteiras raciais e sociais. Esse avanço em direção a outros territórios encontra a sua figuração simbólica mais acabada nas relações Estácio-Vila I sabel e na parceria I smael Silva-Noel Rosa.

Estácio de Sá, centro propulsor do "samba carioca", do "samba de carnaval" ou do "samba de morro", era, como já vimos, bairro de gente simples. Nele as práticas musicais das classes populares contavam com o talento de pessoas que ganhariam projeção na história da música popular brasileira, como I smael Silva, Bide (Alcebíades Barcelos) e Armando $\mathrm{M}$ arçal. Esbanjando engenho e arte, os sambistas confeccionavam freqüentemente seus próprios instrumentos de percussão, uma forma de tentar contornar crônicos problemas financeiros (consta, por sinal, que Bidefoi o inventor do surdo de marcação utilizado nas escolas de samba, feito de couro de cabrito ou de gato que por vezes se comia aqui ou ali...). Ao compor, em 1936, música e letra da belíssima 0 x do problema, Noel Rosa se rendia aos encantos do samba do Estácio, que admirava de há muito. E exprimia a atração que parcela ponderável das classes médias sentia pelo novo tipo de samba que viera à tona na segunda metade dos anos 20.

Ainda na passagem das décadas de 20 e 30, componentes do Bando de Tangarás tinham lá seus pudores em mexer com "esse negócio de música" e se meter com "gente do rádio". Tamanho preconceito de seto- 
res significativos das classes médias e das elites, em relação ao samba e a cantores profissionais de rádio, levaria o filho de um executivo de indústria, o tangará Carlos Alberto Ferreira Braga (Braguinha), a adotar o pseudônimo de João de Barro ou mesmo de Furnarius Rufus, nome pelo qual é conhecido o pássaro joão-de-barro no jargão científico.

Noel Rosa, no entanto, lançaria uma ponte entre bairros e segmentos sociais diversos, e transitaria muito à vontade entre os bambas do Estácio. "Poeta da Vila", el e reconhecia como ninguém o Feitiço da Vila (I sabel) nos versos com os quais deu voz à sofisticada melodia de Vadico: "Quem nasce lá na Vila/ nem sequer vacila/ ao abraçar o samba/ que faz dançar os galhos do arvoredo/ e faz a lua nascer mais cedo." Não era para menos. A Vila Isabel de fins dos anos 20 e início dos 30 transpirava musi calidade. Tanto que o compositor e radialista $\mathrm{Ha}$ roldo Barbosa costumava, muitos anos mais tarde, compará-la à I panema da década de $60 .{ }^{8}$ Point do agito cultural, a Vila, bairro de classe média, legou à história da música e do rádio no Brasil nomes da envergadura de Almirante, João de Barro, Francisco Alves, Nássara, Cristóvão de Alencar, Orestes Barbosa, Antonio Almeida, Ciro de Sousa, J. Cascata, os irmãos Eval do Rui e H aroldo Barbosa, Barbosa Jr. etc., mais "agregados" como Lamartine Babo e as amizades "estranhas" de Noel, recrutadas entre "gente do morro". ${ }^{9}$

M as não se pense que a Vila cultivasse pretensões hegemônicas relativas à apropriação do samba, apesar de sua contribuição para o refinamento da canção popular no Brasil. 0 que se evidencia nas palavras de Noel Rosa é que o samba carioca não pertence ao Estácio ou à Vila I sabel. Ele é produto do Rio de Janeiro, como está dito com todas as letras em Palpite infeliz, com Araci de Almeida: "Salve Estácio, Salgueiro, M angueira/ Oswaldo CruzeM atriz/ quesempresouberam muito bem/ que a Vila não quer abafar ninguém/ Só quer mostrar que faz samba também."

Como que pondo fim, musicalmente, a qualquer discussão sobre a oposição morro x cidade, o mesmo Noel, figura central na definição das fei ções do samba urbano carioca, dissera de maneira categórica, dois anos antes (1933), em Feitio de oração (dele e de Vadico), que “o 
samba na realidade/ não vem do morro nem lá da cidade/ e quem suportar uma paixão/ sentirá que o samba então/ nasce do coração".10

Diferentemente, porém, dos compositores de sua origem social, Noel Rosa demonstrava um apego às coisas e às pessoas do subúrbio e do morro que, também sob esse aspecto, o transformava num tipo excepcional, cruzando e intercruzando mundos distintos, numa palavra, aproximando-o como autêntico "mediador cultural". ${ }^{11}$ Francisco Alves tinha um faro fora do comum para garimpar novidades e talentos onde quer que eles surgissem, para em seguida gravar discos de sucesso. Noel ia muito além: de modo mimético integrava-se aos “sambistas de morro", como atestam as suas parcerias com Canuto (do Salgueiro), Cartola e Gradim (da M angueira), Ernani Silva, o Sete (do subúrbio de Ramos), Bide el smael Silva (do Estácio), sem falar no exímio ritmista Puruca, em Antenor Gargalhada e outros mais. ${ }^{12} \mathrm{~N}$ ão é por si só emblemático que o ex-estudante de M edicina e boêmio Noel Rosa tivesse justamente em I smael Silva o parceiro com quem mais músicas compôs? Justo ele, um negro pouco afeito ao trabalho que, imbuído do orgulho de criador artístico de respeito, vivia de biscates e trapaças de jogo.

A vida e a obra de Noel Rosa fornecem um testemunho eloqüente do movimento de transregionalização do "samba carioca". Gerado numa determinada região do Rio de Janei ro, o samba migra, num processo dinâmico de constante recriação, para outras áreas da cidade. Ao mesmo tempo, conduzido pelas ondas do rádio, ele se desloca para outros lugares do país, o que elevaria o "samba carioca" à condição de samba nacional, embora não se excluam outras pronúncias ou outras dicções do samba. ${ }^{13}$

Esse reconhecimento está presente na linguagem musical dos sambistas. "O samba já foi proclamado/ sinfonia nacional", enfatizavam, em 1936, por meio de Carmen M iranda, os compositores Custódio M esquita e M ário Lago, em Sambista da Cinelândia. Enquanto isso, o piano de Custódio M esquita, com sua habitual elegância, aderia em breves passagens à pulsação rítmica da batucada. ${ }^{14}$ A parentemente haviam sido derrotados os preconceitos mencionados, dois anos atrás, por Maércio de Azevedo e Francisco M atoso em Abandona o precon- 
ceito, com o Bando da Lua. Afinal, em 1935, numa gravação em que música, letra e acompanhamento do conjunto regional se acham estreitamente ajustados, Carmen M iranda cantava em Se gostares de batuque, cuja autoria se atribui a Kid Pepe:

Oi, se gostares de um batuque/ Tem batuque que é produto nacional/ Sobe o morro e vai ao samba/ E lá verás que gente bamba/ Está sambando no terreiro/ Pois tudo aquilo ébem brasileiro.

E isso com direito, no final, a um provocativo e escrachado yeah!

YES, NÓS TEMOS SAMBA: O NACIONALISMO MUSICAL

Yes, nós temos samba. E o samba se converteria na principal peça da artilharia musical brasileira na luta desencadeada contra as "más influências" culturais norte-americanas, que, no front da música popular, seriam encarnadas acima de tudo pelo fox-trot. Se para uns era perfeitamente aceitável que o sambista e o compositor de fox habitassem uma mesma pessoa, para outros essa dualidade era intragável. Se deambos os lados se podiam recolher manifestações em defesa do samba como símbolo musical da identidade nacional, os usos de um ritmo de procedência estrangeira os dividiam, apesar de poderem até atuar como parceiros, como foi o caso, por exemplo, de Noel Rosa e Custódio M esquita.

Quando se pesquisam os registros fonográficos, o que se constata é que o samba - originariamente ligado à idéia de festa regada a música - começa a ser designado como gênero específico na primeira metade da década de 10. Após conhecer um incremento substancial nos anos 20, tanto sob o rótulo de samba como de samba carnavalesco, torna-se hegemônico na década de 30, no terreno da produção musical brasileira. ${ }^{15}$

Ao se examinar a discografia brasileira em 78 rpm, verifica-setambém que há elementos expressivos da penetração do fox-trot desdea segunda metade dos anos 10. A influência de gêneros musicais norte- 
americanos, com o fox à frente, acentuou-se na década de 20. Era a época da formação de diversas jazz-bands, dentre as quais a do BataIhão Naval do Rio de Janeiro. ${ }^{16}$ Nos anos 30 , o fox-trot rodava pelo mundo com inegável sucesso e, no Brasil, sua presença continuou a crescer, notadamente na primeira metade da década, para depois voltar a estar em grande evidência até, grosso modo, o término da Segunda Guerra Mundial.

Durante esses aproximadamente 30 anos do fox-trot em terras brasileiras, as etiquetas dos discos aqui gravados fizeram menção a uma variada gama de foxes: fox-canção, fox-cançoneta, fox-cowboy, foxmarcha, fox-sertanejo e... fox-samba. E se ouviram foxes nacionais e estrangeiros, no original ou em versões (em compensação, se gravaram fado-samba, guarânia-samba, mazurca-samba, samba-rumba, samba-tango e... samba-fox, sem contar samba-boogie e samba-swing).

Armado esse cenário, pode-se então compreender por que, já em 1930, num samba amaxixado de Randoval M ontenegro, Carmen M iranda descarregava a ira dos nacionalistas contra o fox- trot, esse intruso, e espalhava aos quatro cantos que Eu gosto da minha terra:

Sou brasileira, reparem/ No meu olhar, que ele diz/ E o meu sabor denuncia/ Que eu sou filha deste país// Sou brasileira, tenho feitiço/ Gosto do samba, nasci pra isso/ 0 fox-trot não se compara/ Com o nosso samba, que é coisa rara.

E por aí ia esse precursor do samba-exaltação, a transbordar de felicidade com as belezas naturais do Brasil. Sem ser dado a compartiIhar de qualquer ufanismo tolo - supondo-se, é claro, a possibilidade de existir ufanismo que não seja tolo - , Noel Rosa era um dos que compactuavam, no entanto, com as restrições feitas ao modismo do fox-trot. Na verdade, com freqüência ele torcia o nariz diante do que Ihe parecesse americanizado, da mesma maneira como achava deplorável ver brasileiros cantando em outras línguas. Nas palavras dos seus melhores biógrafos, "os estrangeirismos simplesmente não combinam com seu jeito de ser. São chiquês de grã-finos e intelectuais enfatuados, pura moda, mania de exibição". Sob a ótica de N oel, o Brasil está 
aqui perto, na cidade do interior, no morro, no bairro, na esquina. $\mathrm{Ou}$ mesmo no botequim, na gafieira, na pensão de mulheres, no carnaval, na roda de jogo, nos lugares, enfim, onde todos os brasileiros se igualam. Seu nacionalismo tem esse sentido. De gostar das "coisas nossas". De preferir o samba ao fox-trot. ${ }^{17}$

Tudo isso está sintetizado de forma magistral por Noel Rosa numa composição de 1933, Não tem tradução, na qual música e letra se integram à perfeição num só corpo, em sua investida contra aqueles que, "dando pinote", apenas queriam "dançar o fox-trot":

Tudo aquilo que o malandro pronuncia/ Com voz macia/ É brasileiro, já passou de português/ Amor, lá no morro, é amor pra chuchu/ As rimas do samba não são "I love you"/ Esse negócio de "alô", "alô, boy" / "Alô, Johnny"/ Só pode ser conversa de telefone.

M úsica-plataforma, por assim dizer, $\mathrm{N}$ ão tem tradução entrava em linha de sintonia com Macunaíma, personagem concebido pelo modernista M ário de Andrade, que já percebera e procurava apre(e)nder as "duas línguas da terra, o brasileiro falado e o português escrito". ${ }^{18}$ Como se sabe, M ário de Andrade nutria o desejo de captar a fala que nasce do Brasil popular, do "Brasil brasileiro", como que a saborear o coco que o coqueiro dá. N essa perspectiva, a sintaxe é submetida a um processo de abrasileiramento em busca de uma língua brasileira. E essa sintaxe, musicalmente falando, para Noel era o samba. ${ }^{19}$

Ainda em N ão tem tradução, o cinema falado era acusado como "o grande culpado" por umas tantas transformações em curso. Seria, de fato, o cinema falado o vilão apontado por Noel Rosa? Exageros à parte, era indiscutível que, ao desembarcar no Brasil em 1929 - trazendo a bordo o idioma inglês e os musicais norte-americanos - , ele contribuiria poderosamente para originar uns tantos modismos. Do cultivo da aparência física ao vestuário, passando pela incorporação de expressões inglesas à linguagem cotidiana, seu raio de influência foi amplo.

Nacionalista assumido, Assis Valente se insurgia igual mente contra esse estado de coisas. Mulato de origem humilde, que dividia seu 
tempo entre a arte de fazer prótese dentária e a arte de compor, ele aconsel hava em Good-bye, uma marcha de 1932: "good-bye, boy, goodbye, boy/ deixa a mania do inglês/ fica tão feio pra você/ moreno frajola/ que nunca freqüentou/ as aulas da escola". Aliás, já na sua estréia em disco, com Tem francesa no morro, ele confiava a Araci Cortes, estrela cintilante do teatro de revista nas décadas de 20 e 30, a missão de mostrar, com muita graça, que samba e "morrô" ( ou seria "morreau"?) não rimavam com França: "vian/ petite francesa/ dancê/ le classique/ em cime de mesa". Alguns anos mais tarde, em O ui... oui..., Floriano Pinho bateria na mesma tecla: "as francesas sambando/ eu fiquei a sorrir/ marcação de bailado/ à moda chic de Paris!/ (...) no Brasil o samba é patenteado/ e nós, os brasileiros, somos diplomados".

As conseqüências da chegada do cinema falado ao Brasil não se resumiam, contudo, ao domínio dos costumes. Ela provocou, no começo dos anos 30, desemprego em massa de instrumentistas, até então habitualmente convocados para trabalhar nas salas de projeção ou nas salas de espera dos cinemas. 0 número de músicos atirados ao "completo abandono" era calculado em cerca de 30.000 por todo o país. Daí uma manifestação de protesto da corporação musical do Rio de Janeiro, empenhada em assegurar espaço para a apresentação de orquestras típicas nacionais. ${ }^{20} \mathrm{~A}$ idéia que animava os músi cos brasileiros era a de fazer frente às jazz-bands, estrangeiras ou nacionais, surgidas sob inspiração do figurino norte-americano, bem como às orquestras típicas argentinas. M as a proposta, por falta do esperado amparo oficial, caiu no vazio.

O panorama musical brasileiro da época era, obviamente, um campo de forças, com suas disputas e concorrências. 0 samba, hegemônico, não reinava sozinho, como também é óbvio. ${ }^{21} 0$ levantamento dos gêneros musicais veiculados no mundo dos discos indicava, em segundo lugar, a gravação de marchas ( por sinal, era muito comum a dobradinha samba-marcha em cada lado dos discos em 78 rpm, especialmente nos meses que antecediam o carnaval). Gravavam-se em grande quantidade canções, val sas (estas, quase exclusivamente de autores nacionais, em escala bem maior que o fox), músicas sertanejas ou regionais (agrupando muitos gêneros ou subgêneros). Sem o mesmo 
peso quantitativo de antes, o choro era outra modalidade sempre presente, inclusive sob a nova denominação de samba-choro. Já o sambacanção, que despontara como rubrica musical em 1928, ainda contava com um número de registros relativamente reduzido.

O fado, o tango e o fox-trot eram, sem dúvida, os gêneros populares estrangeiros mais em voga nos anos 30, no Brasil. A maior influência, entretanto, continuava a ser exercida pelos foxes, nacionais ou estrangeiros (incluindo-se versões de João de Barro, Alberto Ribeiro, Lamartine Babo e O restes Barbosa, muitas delas de filmes musicais norte-americanos). 0 versionista-mor do momento era Osvaldo Santiago, posto ocupado por Haroldo Barbosa na década de 40. M esmo Orestes Barbosa, nacional ista atéa medula, figurou como co-autor de fox-canções e de fox-trots, em parceria com o maestro J. Tomás. Chegariam ao ponto de compor um fox-samba, Flor do asfalto, em 1931. N esse terreno, todavia, ninguém excedeu musicalmente em qualidade Custódio M esquita, com impecáveis composições em que dava mostras da assimilação criativa de procedimentos musicais norte-americanos, tal como em Nada além (dele e M ário Lago) e M ulher (dele eSadi Cabral).

N esse cenário, de novo se pode recorrer a Noel Rosa como uma espécie de tipo-ideal weberiano da trincheira do samba. 0 exame da sua obra é um atestado disso. N um esforço de recuperação meticuloso, João M áximo e Carlos D idier ${ }^{22}$ arrolaram 259 canções de N oel. A imensa maioria de suas composições é constituída por sambas, 164 ao todo, dos quais, na prática, se se considerar a existência de diversas parcerias fictícias, cerca de metade é tão-somente dele. Bem mais abaixo aparecem as marchas, 31 no total, 23 delas em regime de parceria. Todos os demais gêneros têm uma presença pouco significativa no conjunto da produção de Noel.

Em sua curta vida, interrompida por complicações pulmonares aos 26 anos, nada mais do que um fox-trot com letra sua (música do irmão Hélio Rosa, aliás, coisa de irmão para irmão) chegou ao disco: Vocêsó... mente. Estátua da paciência, com melodia do regente de orquestra de teatro de revista Jerônimo Cabral, teria que amargar mais de 50 anos de esquecimento até ser gravada pela primeira vez pelo Conjunto Coisas N ossas.

Gozador de marca maior, Noel foi autor de operetas, óperas bu- 
fas cariocas ou revistas radiofônicas. Parodista implacável, parodiou a si próprio com a mesma facilidade com que seus traços o caricaturizaram, ele que, "sem queixo", fazia a alegria dos caricaturistas. É sabido que o procedimento parodístico sublinha a diferença, quando não institui a inversão. Afasta-se radicalmente da paráfrase, que atua como recurso argumentativo de reforço e de cel ebração da identidade. No caso, a ação de Noel novamente o aproxima de um dos elementos críticos utilizados pelos poetas modernistas, o poema- piada, em meio à reavaliação que fizeram, nos anos 20, da cultura brasileira. ${ }^{23}$

O nacionalismo popular de Noel não se permite arrebatamentos ou derramamentos grandiloqüentes. 0 Brasil Ihe deu régua e compasso para desenhar o "Brasil de tanga", o Brasil da "prontidão". De olhos voltados para o corpo-a-corpo do dia-a-dia, seu universo é povoado pela mulher, pelo pandeiro, batuque, violão, prestamista e vigarista, como em Coisas nossas, que el canta com sua voz pequena e em tom coloquial: "malandro que não bebe/ que não come/ que não abandona o samba/ pois o samba mata a fome/ (...) e o bonde que parece uma carroça/ coisa nossa, muito nossa"!

Noel Rosa, Ari Barroso, João de Barro, Alberto Ribeiro e muitos outros tinham em comum traços nacionalistas, mais ou menos pronunciados, e, quaisquer que fossem as diferenças que os separassem, elegiam o samba como produto nacional. Com a marchinha Yes! Nós temos bananas..., êxito carnaval esco de 1938 em diante, João de Barro e Alberto Ribeiro faziam uma réplica a um fox-trot que deu volta ao mundo, Yes! We have no bananas, de Frank Silver eI rving Cohn. Isso equivalia a um brado nacionalista de quem se sabia subdesenvolvido, sim, mas achava, ainda assim, razões para se orgulhar de seu país: "Yes! nós temos banana/ banana pra dar e vender/ banana, menina/ tem vitamina/ banana engorda e faz crescer." E, musicalmente, quem ia para o trono no Brasil era, de fato, o samba, como cantava Almirante em Touradas em M adri, da mesma dupla que se celebrizou com suas marchas:

Eu conheci uma espanhola/ Natural da Catalunha/ Queria que eu tocasse castanhola/ E pegasse o touro à unha/ Caramba/ Caracoles/ Sou do samba/ Não me amoles/ Pro Brasil eu vou fugir/ Isso é conversa mole/ Para boi dormir. 
A escalada do samba para obter seu lugar ao sol entre os símbolos nacionais levou-o a percorrer territórios minados. Sofrendo nos primeiros tempos com as investidas policiais, que não poupavam a malandragem e a capoeiragem, ele foi achincalhado como "coisa de negros e de vadios". O violão, companheiro das horas certas e incertas, foi desqualificado como "instrumento de capadócios".24

0 reconhecimento de que o samba era negro de nascença provinha inclusive de compositores e intérpretes brancos que não viam nisso, necessariamente, algo de negativo. Como no amaxixado 0 nego no samba (de Ari Barroso, Luiz Peixoto e M arques Porto), com Carmen M iranda, que zombava, em 1929, da falta de jeito dos brancos ao caírem no remelexo do samba:

Samba de nego/ Quebra os quadri/ Samba denego/ Tem parati/ (...) N um samba, branco se escangaia/ N um samba, nego bom de saia/ Num samba, branco não tem jeito, meu bem/ Num samba, nego nasce feito.

Coisa de nego que envolve negaça ( sedução, provocação, requebro) e parati (cachaça) para festejar o momento lúdico, eis, em suma, o retrato falado do samba. Poucos anos depois, já não seria esta a imagem que outros compositores fariam dele.

$\mathrm{N}$ a realidade, 0 samba - no seu fazer-se e refazer-se permanente - ia incorporando outra tez e outro tom, quer dizer, outras dicções e tonalidades, imerso num processo simultâneo de relativo embranquecimento e empretecimento dos grupos e classes sociais que lidavam com ele. Sua prática o conduzia rumo a direções opostas e complementares, tecendo a dialética da unidade dos contrários, tão bem expressa nas contraditórias trocas culturais realizadas entre as classes populares e as classes médias. Pavimentava-se o caminho para a entronização do samba como ícone cultural de toda a nação e não apenas desse ou daquele segmento étnico ou social. Testemunha ocular e ativo participante dessa história da nacionalização do samba, Orestes Barbosa pres- 
tava o seu depoimento em Verde eamarelo, calcado em música de J. Tomás, revelando, em 1932, sinais de um novo tempo:

Vocês quando falam em samba/ Trazem a mulata na frente/ M as há muito branco e bamba/ Que no samba é renitente/ $\mathrm{N}$ ão me falem mal do samba/ Pois a verdade eu revelo/ 0 samba não é preto/ 0 samba não é branco/ O samba é brasileiro/ É verde e amarelo.

Para acentuar o clima nacionalista, essa gravação é entrecortada por acordes do hino nacional. E mais: nos versos seguintes ("nesta terra de palmeiras/ onde canta o sabiá/ as almas das brasileiras/ são da flor do resedá") há uma citação de Canção do exílio, de Gonçalves Dias, poeta romântico repetidamente parodiado pelos modernistas. Nada aí é casual: 0 arremate recorda a coloração amarela da flor do resedá.

O Brasil parecia se encher de cores, a julgar ainda pela denominação de al gumas formações musicais, como o Grupo Verde eAmareIo, a Dupla Preto e Branco e a Dupla Verde eAmarelo. Tudo isso devia ser sintoma de alguma coisa. Sintoma da mestiçagem que passou a ser cantada e decantada como nunca se viu por estas terras. Sua trilogia pode ser buscada, por exemplo, na seqüência das marchas compostas por um dos maiores nomes dos carnavais brasileiros, o branco Lamartine Babo, originário da classe média. Em 0 teu cabelo não nega (delee dos Irmãos Valença), de 1931, a mulata é reverenciada. No ano seguinte ela cede seu lugar à Linda morena. Em 1933 ele cantaria Dá cá o pé... loura (delee de Alcir Pires Vermelho).

Em síntese, o que se tematizava musicalmente não era senão o caráter "misto", "multirracial" da sociedade brasileira. A miscigenação, ora execrada, ora enaltecida, permanecia no centro de debates intelectuais que punham à mostra como a questão da identidade nacional se ligava umbilical mente à temática racial. 0 antropólogo Gilberto Freyre ${ }^{25}$ louvaria a miscigenação brasileira como a simbiose de negros, índios ebrancos com final supostamentefeliz na história do Brasil. ${ }^{26} \mathrm{Sim}$ biose que seria retratada em mais uma marcha de Lamartine Babo, $\mathrm{H}$ ino do carnaval brasileiro, na qual ele resume, de certa forma, suas três composições anteriores ejoga com outros símbolos nacionais: "sal- 
ve a morena!/ a cor morena do Brasil fagueiro/ (...) salve a loirinha!/ dos ol hos verdes, cor das nossas matas/ salve a mulata!/ cor do café, a nossa grande produção".

Outros autores consagrariam indistintamente as loiras eas morenas, como Jaime Brito e Manezinho Araújo em Lalá e Lelé, com Luiz Barbosa. Cantor cheio de bossa, criador do samba de breque, Luiz Barbosa batucava na copa de seu chapéu de palha - "instrumento de percussão" patenteado por ele - para homenagear alegremente a loira Lalá ea morena Lelé, "duas garotas do desacato", que "quando caem no samba/ (...) provocam até cenas de pugilato".

O leque da miscigenação na música popular se abre por inteiro, todavia, na marcha É do barulho (de Assis Valente e Zequinha Reis). N ela se encontram referências explícitas às morenas, loiras, mulatas e crioulas. E se afirma, em al to e bom som: "sou pacificador/ não quero brigar/ por causa de cor/ (...) todas elas são rainhas/ de igual valor". 0 Bando da Lua interpreta essa canção harmonizando vozes da mesma maneira como idealmente se harmonizam cores e raças no Brasil.

Esse policromatismo, base sobre a qual se erigiu o mito da democracia racial brasileira, consistia num dos pontos de partida de reflexões político-sociais de pensadores ideologicamente comprometidos com a ditadura estado-novista. Cassiano Ricardo não secansava de elogiar o "berreiro cromático" ou o "escândalo" de cores chamado Brasil. Nacionalista de corte autoritário, à moda dos ideólogos de Estado, ${ }^{27}$ ele, ao reescrever a história do Brasil, enfatizava: "parece que D eus derramou tinta por tudo". Da exaltação à natureza à exal tação da fábula das três raças (índios, negros e brancos) era um passo: "todas as cores raciais na paisagem humana". ${ }^{28}$

M as nem tudo era consonância quando a questão dizia respeito à raça e ao samba. Vozes dissonantes também se faziam ouvir, quebrando a aparente harmonia estabelecida. No palco de disputas montado em torno dos destinos da música popular não faltaram ataques de fundo racista. 0 samba do morro, por exemplo, ficou sob a alça de mira de articulistas inconformados com a propagação dessa "coisa de negros". Um deles, Almeida Azevedo, pegava pesado contra esse estilo de samba ao escrever, em março de 1935, na revista A Voz do Rádio. Qua- 
lificava-o de "maltrapilho, sujo, malcheiroso", incriminando-o como o "irmão vagabundo" do samba "que não quer limpar-se nem a cacete". Daí apelar para os responsáveis pelas emissoras de rádio: “o rádio pode, se o quiser, higienizar o que por aí anda com o rótulo de coisas nossas a desmoralizar a nossa cultura e bom gosto". ${ }^{29}$

Isso representaria, aos olhos desses críticos "refinados", um desacato aos nossos padrões de civilidade. Desacatar, aliás, era um verbo muito conjugado por sambistas ao fazerem alusão a mulatas do desacato, a sambas que desacatavam, no sentido de "botar pra quebrar". Nessas circunstâncias é que, na esteira do sucesso que Carmen M iranda começava a al cançar nos Estados Unidos, foi detonada, em meados de 1939 - por intermédio de A N oitee 0 Jornal - , uma polêmica que tinha como contendores Pedro Calmon e José Lins do Rego. Um, historiador, que não escondia seus pressupostos racistas, outro, romancista, ambos preocupados com o samba. ${ }^{30}$

Tal debate se vinculava, pelo menos em parte, a outra discussão que, volta e meia, sacudia a música popular ao longo dos anos 30. Entrava então em pauta a "higienização", o "saneamento" do samba ou, no dizer de Almirante, a necessidade de "regeneração dos temas poéticos da música popular". ${ }^{31}$ Vale relembrar que, quando o mulato semialfabetizado Wilson Batista compôs, em 1933, Lenço no pescoço, cantado malandramente por Sílvio Caldas, esse samba desatou uma controvérsia que se arrastou por al gum tempo. NeleW ilson Batista se referia a um determinado tipo de malandro em tom de glorificação: "meu chapéu de lado/tamanco arrastando/ lenço no pescoço/ navalha no bolso/ eu passo gingando". A reação foi imediata. Orestes Barbosa, na sua pioneira coluna de rádio no jornal A H ora, estrilou: "num momento em que se faz a higiene poética do samba, a nova produção de Sílvio Caldas, pregando o crime por música, não tem perdão". ${ }^{32} \mathrm{E}$ tanto não teve perdão entre os guardiães dos bons costumes que a comissão de censura da Confederação Brasileira de Radiodifusão vetou sua irradiação. ${ }^{33}$

Outro defensor do saneamento musical do Brasil era Joubert de Carvalho. Filho de fazendeiro, médico, socialmente muito bem relacionado, ele apreciava músicas eruditas. Sem maior intimidade com o 
samba, seu forte eram as composições românticas, "músicas para uso interno". Numa década de inequívoco domínio do samba como gênero musical, Joubert de Carvalho propunha um deslocamento do eixo sobre o qual se apoiava a música popular brasileira e, em descompasso com osadeptos da miscigenação, clamava pela valorização da raça branca. Em Sai da toca, Brasil!, de 1938, afirmava que senzala, macumba, 0 bater o pé no chão, tudo isso pertencia ao passado: "a dança agora éno salão". Para elevar o Brasil ao foro de civilidade, urgia trocar a favela pelo arranha-céu. E ponderava: "Brasil das avenidas/ da praia de Copacabana e do asfalto/ a tua gente branca e forte/ ninguém cantou ainda bem alto." Em tempo: Sai da toca, Brasil! era uma rumba...

A resposta não se fez por esperar. Vestindo a carapuça, Nelson Petersen, integrante do Bando Carioca, replicou num diapasão francamente nacionalista. Em Q uem condena a batucada ele ia direto e reto ao assunto: "quem condena a batucada/ dessa gente bronzeada/ não é brasileiro/ e nada mais bonito é/ que um corpo de mulher/ a sambar no terreiro". Era uma quimera, no seu entender, alguém pensar em acabar com o samba e a malandragem. 0 samba que, frisava N elson Petersen, "nasceu num cruel barracão" e"foi educado sambando no chão/ com a gente de cor".

Por um tempo as resistências ainda iam estalar, aqui ou ali. Todas elas, no entanto, seriam insuficientes para barrar a consagração do samba como símbolo nacional eícone musical da mestiçagem. Com tudo o que Carmen M iranda pudesse ter de expressão caricatural, característica de um "exotismo apimentado" (basta mencionar a salada de frutas que carregava sobre a cabeça, a sua imagem mais difundida no exterior), ela não deixou de personificar o paradigma mestiço. Como sublinha Hermano Vianna, "branca européia, Carmen M iranda não via nenhuma contradição em se vestir de baiana (usando a roupa 'típica' das negras da Bahia), ou em cantar ou dançar samba (música de origem negro-africana)". ${ }^{34}$

N esse contexto, afinal, "chegou a hora/ dessa gente bronzeada/ mostrar seu valor", como reivindicou Assis Valente na esfusiante Brasil pandeiro. Os ganhos advindos da nacionalização do samba não foram, porém, divididos na sua justa proporção. Os cantores brancos de clas- 
se média com certeza estavam entre os que mais tiraram proveito do fato do samba atingir a crista do sucesso. Multiplicavam-se as queixas de compositores das classes populares sobre a dificuldade de acesso às gravadoras, que acumularam lucros e mais lucros com a exploração do trabal ho alheio. Criadores do nível de Bide e M arçal, de origem negra, se profissionalizaram, quer em rádios quer em gravadoras, figurando como simples acompanhantes. Eles, os bambas, relegados a pano de fundo como ritmistas... Por sua vez, os proprietários das emissoras de rádio lançaram mão até de lockout a fim de conservar no mais baixo patamar possível a remuneração dos direitos autorais. ${ }^{35}$ Enfim, nada de novo sob o sol. Na sociedade de classes a acumulação do capital se dá, em regra, exatamente assim.

MULATO FILHO DE BAIANA E GENTE RICA DE COPACABANA: O SAMBA DE TODAS AS CLASSES

M esmo com a desigualdade que imperava na hora da distribuição dos lucros gerados pela rede de negócios em volta da mercadoria samba, este, em termos gerais, se converteria em ponto de atração e de encontro das mais diferentes classes sociais. U m Brasil, digamos, pluriclassista se reúne e se concilia ao redor do samba. M oda que se espraia, sua mobilidade social abarca amplos segmentos, como já documentava Josué de Barros numa composição de 1929, o choro Seo samba émoda (lado B do disco de estréia de Carmen M iranda):

O samba era/ Original dança dos pobres/ E, no entanto, hoje/ Vive nos salões mais nobres/ (...) Ainda há quem diga/ Que o samba não tem valor/ M as lá se encontra/ $O$ deputado e o senador.

N ovos cenários acolhiam o samba entre fins dos anos 20 e princípio da década de 30. E eles não passaram despercebidos a observadores atentos da cena musical, como Pixinguinha e Cícero de Almeida (Baiano). Na interpretação despojada de Patrício Teixeira, o partido-alto Samba defato (que era, de fato, um samba-choro), de 1932, registrava: 
Samba do partido-alto/ Só vai cabrocha/ Quesamba defato (estribilho)// Só vai mulato filho de baiana/ $\mathrm{E}$ a gente rica de Copacabana/ Dotô formado de ané de oro/ Branca cheirosa de cabelo louro, olé.

Apesar de reconhecer que "no samba nego tem patente" e, mais, que no samba sem cachaça "a boca fica com um gosto mau/ de cabo velho de colher de pau", celebra-se o congraçamento social promovido por esse ritmo que se nacionaliza. É como se, do subúrbio à "cidade", ninguém conseguisse escapar à sua pulsação, fruindo o Sabor do samba, título de uma composição, de 1935, assinada por Kid Pepe e Germano Augusto:

Peço licença pra dizer/ Que hoje em dia/ O samba lá no morro/ Também tem sua valia/ Eu fui a um samba/ $\mathrm{Na}$ alta sociedade/ Vendo sambista de smoking/ Eu me senti à vontade.

Se nesses exemplos de conciliação social via samba os sambistas comemoram, em última análise, o reconhecimento por outras camadas sociais da importância da sua criação, haverá casos, no campo da produção musical, em quese procurará deliberadamente, de forma programática, a harmonização das classes sociais. É o caso do compositor e regente da área erudita H eitor Villa-Lobos, empenhado em puxar 0 coro da unidade nacional. Na sua visão, afinada com a de outros músicos modernistas, a música deveria servir como uma alavanca para a integração social e política sob a batuta estatal e como instrumento de exaltação da disciplina e do civismo. ${ }^{36}$

Pelo mundo afora estava na ordem do dia o combate sem tréguas à luta de classes com o objetivo de impedir o avanço da "barbárie comunista". E para tanto, como garantia, num discurso de 1937, o futuro ministro da Justiça estado-novista Francisco Campos, sabia-se a que recorrer, pois só "o corporativismo interrompe o processo de decomposição do mundo capitalista previsto por Marx como resultante da anarquia liberal". ${ }^{37}$

Enquanto isso, sem maiores preocupações com os problemas políticos conjunturais, os sambistas iam, na prática, ao som da batucada, 
aproximando as classes sociais. Até no plano estritamente sonoro tal fato podia ser percebido, por exemplo, com os rearranjos feitos, no decorrer do tempo, na composição da família instrumental do samba. Ao se referir ao conjunto Gente do M orro - um grupo regional cujas gravações vão de 1930 a 1934 e cujo nome, a julgar pela procedência de seus componentes fixos, era mais uma espécie de fachada comercial - , Tinhorão chama a atenção para a simbiose musical que ele representava:

(...) o que o conjunto Gente do M orro fazia - e isso era de fato novidade - era realizar a fusão dos velhos grupos de choro à base de flauta, violão e cavaquinho com a percussão dos sambas populares herdeiros dos improvisos das rodas de batucada, com base em estribilhos marcados por palmas. Sob o nome logo popularizado de conjunto regional, o que tais grupos vinham a realizar (o próprio líder do Gente do M orro à frente, com seu depois famoso Conjunto de Benedito Lacerda) era o casamento da tradição do choro da pequena classe média com o samba das classes baixas. ${ }^{38}$

A adesão da classe média ao samba, em meio à sua recriação incessante, contou com exemplos notáveis. Sem falar novamente de Noel Rosa, podem ser lembrados os bacharéis em Direito Ari Barroso e M ário Lago, o médico homeopata Alberto Ribeiro, além de Custódio Mesquita, moço de "boa família", regente diplomado pela Escola Nacional de M úsica, e muitos outros mais. No nível estilístico, uma evidência a mais se corporifica na aparição, em 1928, de um gênero ou subgênero musical - o samba-canção - que buscava maior apuro melódico e que teria como marco Ai, ioiô, de Henrique Vogeler. Lançada com sucesso a partir de 1929, sob quatro títulos diferentes e, na falta de uma, ostentando três letras, sua versão definitiva - com o título de laiá surgiria em março desse ano, com uma dicção interpretativa um tanto quanto operística de Araci Cortes, escorada por um acompanhamento da O rquestra Parlophon com acento amaxixado.

O samba-canção - estilo particularmente adequado ao período de entrecarnavais, e que fazia parte do conjunto das então denominadas músicas de-meio-de-ano - de início deslancharia junto a compo- 
sitores que sabiam ler música (como Ari Barroso e Custódio M esquita), alguns inclusive com formação erudita. Posteriormente, num movimento de sentido contrário ao do samba, stricto sensu, ele expandiria seu alcance em direção às classes populares. Historicamente, Cartola e N elson Cavaquinho são exemplos marcantes desses intercâmbios culturais, testemunhados por Roberto Martins e Waldemar Silva em Favela, de 1936, ao cantarem a "favela dos sonhos de amor/ e do sambacanção".

As relações entretidas entre a classe média e a "gente do povo" estão flagradas em diversas canções. Não foram Vadico e Noel Rosa, dois compositores provenientes das camadas médias da sociedade que, em Feitiço da Vila, já afirmavam que "lá em Vila Isabel/ quem é bacharel/ não tem medo de bamba"? Três anos depois, em 1937, com sua veia satírica saltada, Assis Valente produziria mais uma de suas brilhantes crônicas/críticas musicais de costumes. $\mathrm{Na}$ berlinda, um acontecimento que se integrara à vida cotidiana: a escapada de doutores de classe média, fantasiados de malandros, que se entregavam ao reinado da folia nos dias de carnaval. Camisa listada, apesar da rejeição que sofreu da parte de diretores de gravadoras, acabou sendo gravada por Carmen $M$ iranda ante a insistência de Assis Valente e obteria enorme sucesso. $M$ ais ainda: com esse samba-choro se perpetuou uma das mais memoráveis interpretações da "pequena notável", encarnando, aí, a graça em pessoa:

Vestiu uma camisa listada e saiu por aí/ Em vez de tomar chá com torrada/ Ele bebeu parati/ Levava o caniveteno cinto/ E um pandeiro na mão/ E sorria quando o povo dizia/ Sossega leão, sossega leão// Tirou o anel de doutor/ Para não dar o que falar/ E saiu dizendo/ Eu quero mamar/ M amãe, eu quero mamar.

Esse estado de coisas, é lógico, só jogava a favor da nacionalização do samba, na medida em que apagava as linhas demarcatórias que pudessem subsistir, dificultando o livre tráfego do samba pela sociedade. E sem isso dificilmente o samba exibiria suas credenciais de "coisa nossa". Afinal, como demonstrou H ermano Vianna, múltiplos sujeitos so- 
ciais interviriam nesse processo, dentre os quais se deve mencionar "negros, ciganos, baianos, cariocas, intel ectuais, políticos, folcloristas, compositores eruditos, franceses, milionários, poetas". Vem daí que "o samba não se transformou em música nacional através dos esforços de um grupo social ou étnico específico, atuando dentro de um território específico". Do mesmo modo, complementa esse antropólogo, "nunca existiu um samba pronto, 'autêntico', depois transformado em música nacional. O samba, como estilo musical, vai sendo criado concomitantemente à sua nacional ização". ${ }^{39}$

Nada disso, porém, significa que tivesse se evaporado, como que por efeito de um passe de mágica, todo equalquer ressentimento de classe ou a percepção da discriminação social/racial. As contradições inerentes a uma sociedade assentada nas desi gual dades compunham, evidentemente, o dia-a-dia dos sambistas. E Assis Valente, por exemplo, não engolia aquilo que afetava, em especial, as pessoas simples. Assim, em Isso não se atura, de 1935, depois de, sintomaticamente, atirar farpas visando ao pessoal do Café N ice, ele atacava a questão da desigualdade social ou do tratamento diferenciado dispensado pela polícia. D eterminados comportamentos dos sambistas populares, "a polícia não consente/ aparece o tintureiro (carro de polícia, camburão)/ e seu guarda leva a gente", denunciava o autor. Por outro lado, completava, "eu já fui numa macumba/ que no fim o pau comeu/ mas foi entre gente fina/ ea polícia não prendeu".

Apesar da nacionalização do samba em marcha, ainda se guardava, nos setores populares, uma certa distância dos "penetras" de outras classes. Vestígios disto são captados também em Você nasceu pra ser grã-fina. N essa composição Laurindo de Almeida zomba de uma madame que teimava em aprender samba, sem voz, sem ritmo, nem nada que a credenciasse a tanto: "se compenetre/ que o samba é alta bossa/ e é pra nego de choça/ que não fala o inglês". Na mesma linha, na outra face desse disco de 1939, o mesmo autor retratava um M ulato antimetropolitano "que não gosta da cidade", "dispensa o cinema/ e neres (nada) de fox-trot/ é do samba-canção/ (...) e hoje ele vive no morro/ onde há samba pra cachorro/ e o povo é mais igual".

Embora esses exemplos revelem que o discurso musical dos sam- 
bistas não atingira um grau de uniformidade plena, não há como descartar que o tom preponderante apontava para uma relativa comunhão de classes em volta do samba. Q uanto a isso, reafirmo algo que me parece crucial. 0 samba, ao extrapolar os territórios e os grupos sociais de onde se originou, era motivo de orgulho para os sambistas. Numa palavra, ele atuava como fator de afirmação e de identificação socio-cultural de grupos e classes sociais normal mente marginalizados na esfera da circulação dos bens simbólicos. Eles assistiam, com justa satisfação, à transformação, seja lá como for, da obra brotada do seu talento em símbolo de brasilidade.

Custódio M esquita soubeinterpretar como poucos esse sentimento que tomava conta dos construtores do samba em geral, aqui incluída a parcela das classes médias que ele próprio exprimia. Sua canção D outor em samba, de 1933, é por si só eloqüente, não fora ainda a performance do mestre do canto-falado, M ário Reis, bem como a participação primorosa dos Diabos do Céu no acompanhamento:

Sou doutor em samba/ Quero ter o meu anel/ Tenho esse direito/ Como qualquer bacharel/ Vou cantar a vida inteira/ Para meu samba vencer/ É a causa brasileira/ Que eu quero defender// Só o samba me interessa/ E me traz animação/ Quero o meu anel depressa/ Pra seguir a profissão.

O protético Assis Valente, outro doutor não-doutor, manifestava igualmente o sentimento de superioridade dos sambistas na arte de criar música popular. Os termos eram praticamente equivalentes. No clássico M inha embaixada chegou, de 1934, ele recordava que "não tem doutores na favela/ mas na favela tem doutores/ o professor se chama bamba/ medicina na macumba/ cirurgia lá é samba".

Paralelamente, no próprio solo do samba despontariam mediadores políticos e culturais, dentre os quais Paulo da Portela talvez fosse o mais emblemático. Homem muito chegado à imprensa, constantemente em contato com as autoridades, cumpriu a função de aproximar grupos e classes sociais distintos, contribuindo, à sua maneira, para a maior aceitação do samba. Como frisa Sérgio Cabral, "a sua luta consistia em tirar as escolas (de samba) da marginalidade e que não 
fossem mais olhadas como antro de malandros e desordeiros".40 Nesse particular certamente haveria um vasto campo de entendimento entre o mundo do samba e o "grand-monde". E o Estado brasileiro não tinha por que não aplaudir iniciativas do gênero.

Do mesmo modo, soavam, em mais de um sentido, como música, aos ouvidos das classes dominantes e dos governantes, palavras como as do ex-capoeirista H eitor dos Prazeres em favor da regeneração do malandro. É "doloroso", "vergonhoso", "não é negócio ser malandro", pregava ele em Vou ver se posso, enquanto expressava a confiança de que, com trabalho, tudo mudaria. Como quem se demite da mal andragem, anunciava em 1934: "eu vou deixar esta vida de vadio/ ser malandro hoje é malhar em ferro frio". E ainda estávamos um tanto quanto distantes da cruzada antimalandragem patrocinada pelo "Estado Novo", quando, em nome da unidade nacional, todos foram convocados, para dizer o mínimo, a engrossar as fileiras do exército da produção em prol do "progresso nacional".

\section{OS SAMBAS DA MINHA TERRA: CONSIDERAÇÕES FINAIS}

O(s) território(s) do(s) samba(s) permanecerá(ão) em aberto, dotado(s) de fronteiras móveis, nele(s) tendo lugar sempre novos rounds das "lutas de representações". Basta relembrar que, no momento em que a Bossa Nova, a partir do final dos anos 50, avança o sinal e dilata o universo do samba, inúmeras foram as reações de indignação das forças sociais esteticamente mais conservadoras, deflagrando-se um debate musical em escala jamais vista neste país. ${ }^{41}$

No período a que me restringi neste artigo, a vigência do "Estado Novo" e a relação especial que ele estabeleceu com a música popular constituem tema do maior interesse para a análise dos canais institucionais de comunicação que se criaram entre as agências estatais e a produção/difusão do samba. Deliberadamente, pus de lado o enfrentamento dessa questão por não poder, aqui, ir além de uns tantos limites, embora sem ignorar que o Estado, desde meados da década de 30, começava a emitir claros sinais de aproximação com a área da música 
popular (a oficialização do desfile de carnaval pela Prefeitura do Distrito Federal, em 1935, éum indicador disso).

O samba, que já chegara aos cassinos e às telas de cinema, conhecerá, sob o "Estado Novo", o momento de consolidação da sua afirmação como símbolo musical nacional. Despido, pelo menos na versão oficial, dos pecados de origem que o mantiveram à margem dos lugares respeitáveis, o samba ganhava terreno. N ão por acaso, este será o período do florescimento de uma grande safra de sambas cívicos, os chamados sambas-exal tação, dentre os quais sobressairá Aquarela do Brasil, de Ari Barroso, como exemplo mais bem acabado. Essa composição exalava o espírito oficial da época, mesmo sem conter, é bom que se diga, qualquer referência ao regime estado-novista.

Com um ar grandiloqüente, típico de quem transporta para 0 campo da música popular a "estética monumental", essa fornada de sambas-exaltação recorreria a clichês do ufanismo tupiniquim. Da exaltação à natureza se passaria, sem nenhuma dificuldade aparente, à exaltação mais ou menos explícita da vida política brasileira (subentendase, do regime político instituído). Tal foi o caso de Brasil! (de Benedito Lacerda e Aldo Cabral), ou ainda de Brasil, usina do mundo (de João de Barro e Alcir Pires Vermelho), samba que nos coloca diante de trabalhadores cantando felizes, parceiros ou, mais do que isso, cúmplices dos novos tempos simbolizados pelo "Estado Novo".

O nacionalismo espontâneo de compositores de extração popular e/ou de classe média, que se orgulhavam da sua condição de criadores do samba, era, portanto, ressignificado, em sintonia com a política cultural estado-novista. Ao mesmo tempo, as temáticas da mestiçagem e da conciliação de classes eram retrabalhadas pelos ideólogos do regime, tendo em vista o enaltecimento da democracia racial e da democracia social supostamente existentes no país.

Nem tudo, porém, acontecia ao sabor dos desejos dos governantes ou dos defensores do "Estado Novo". O DIP (Departamento de Imprensa e Propaganda) procurava, seja por meio de políticas de aliciamento, seja por meio de uma censura férrea, coagir compositores renitentes a abandonarem o culto à malandragem nos seus sambas. Daí decorreu, basicamente, o aparecimento de uma quantidade apreciável 
de sambas de exaltação ao trabal ho, de autoria até de malandros escolados, como Wilson Batista (o caso mais notório éo de 0 bonde de São Januário, sucesso do carnaval de 1941). Entretanto, nem com recursos de poder draconianos a seu dispor o "Estado Novo" logrou silenciar e/ou cooptar por completo os compositores. Multiplicaram-se às dezenas as composições que, de uma ou outra maneira, driblavam e/ou contornavam a censura ditatorial. ${ }^{42} \mathrm{U}$ ma obra exemplar, nesse sentido, é Recenseamento, de Assis Valente, que, parecendo reproduzir o discurso do "Brasil grande e trabalhador", desmonta com sutileza os argumentos oficiais, salpicando de ironia a fala da mulher que responde ao funcionário público que a interpela.

Desse prisma pode-se dizer que, na verdade, são muitos os sambas da minha terra, até sob a ditadura estado-novista. Nunca se conseguiu uma tal padronização ou uniformização na produção do samba que calasse as divergências, inclusive as diferenças estilísticas. Aliás, nem sequer no interior dos aparelhos de Estado existiu um pensamento único, monolítico, acerca do significado do samba. As contradições e conflitos próprios das lutas de representações afloraram aí também.

$\mathrm{Na}$ ausência de um projeto cultural hegemônico, ${ }^{43}$ distintas propostas de disciplinarização das manifestações artísticas de origem popular terminaram por emergir. Pondo às claras seu ranço profundamente elitista, um grupo de intelectuais ligados ao Estado deu vazão à sua repulsa ao samba em artigos publicados na revista Cultura Política. ${ }^{44} \mathrm{~N}$ ivelando-o a expressões artísticas primitivas, ao desregramento da sensualidade, à batucada da ralé do morro, eles o elegeram como objeto de uma campanha movida por propósitos educativos e civilizadores. Tratava-se não de abatêlo - objetivo que admitiam ser impossível - , mas, sim, de domá-lo.

As disputas iriam se acirrar na própria área da produção do(s) samba(s). De novo a mobilidade de fronteiras do samba se evidenciava. E ele começava, aos poucos, a enveredar, uma vez mais, por territórios inexplorados, como prelúdio de outros tempos que estariam por vir, cenas dos próximos capítulos que desembocariam na Bossa Nova. Sob a rubrica de samba-swing - que por si mesma anunciava a presença e a assimilação de elementos musicais norte-americanos - um 
compositor como Janet deAImeida trazia o futuro para o presente. ${ }^{45}$ Pesadelo (dele e de Leo Vilar), gravado em 1943 pelos Anjos do Inferno, é rico em dissonâncias e recortes harmônicos pouco usuais no Brasil. Daí ao samba Boogie-woogie na favela (de Denis Brean, pseudônimo de Augusto Duarte Ribeiro), de 1945, havia um curto caminho a ser vencido. Apesar da reação dos que, em honra às tradições nacionais, insistiam em argumentar que Boogie woogie não é samba (de Hélio Sindô).

Acima das disputas, pairando sobre as suas diferentes pronúncias, o samba seguia sua(s) trilha(s), consolidado como símbolo da nacionalidade. Expressão cultural plural, ele era glorificado como portador da nossa singularidade musical. E soava como al go tão natural, tão entranhadamente brasileiro, que, em 1940, Dorival Caymmi, já proclamara em Samba da minha terra: "quem não gosta de samba/ bom sujeito não él é ruim da cabeça/ ou doente do pé". ${ }^{46}$

PARANHOS, A. The invention of Brazil as the land of samba: the samba composers and their social affirmation. História, São Paulo, v.22, n. 1, pp. 81 a 113, 2003.

A B STRACT: As in a race of obstacles, samba traveled across bumpy paths until it was recognized by legitimization instances of the State as a national symbol. Throughout this process, the samba composers and interpreters of urban Rio samba played a decisive role. This article searches to clarify some hardly studied aspects of the marches and counter-marches which marked the history of samba and its passage from culturally marginal artifact to the bearer of Brazilian singularity in the musical field.

KEY wo RDs: samba; Brazilian popular music; national symbols.

\section{NOTAS}

${ }^{1}$ Versão ampliada deste texto foi publicada em TORRES, R. (org.). M úsica popular en América Latina, Santiago de Chile: Rodrigo Torres, 1999, pp. 193-232, com o título 0 Brasil dá samba?: os sambistas e a invenção do samba como 'coisa nossa'. 
${ }^{2}$ Departamento de Ciências Sociais - Faculdade deArtes, Filosofia e Ciências Sociais - UFU - 38400-902 - U berlândia - M G.

${ }^{3}$ Ver, entre outros, SODRÉ, M. Samba: o dono do corpo. Rio de Janeiro: Codecri, 1979.

${ }^{4}$ Ver, por exemplo, SADER, E.; PAOLI, M . C. Sobre "classes populares" no pensamento sociológico brasileiro: notas de leitura sobre acontecimentos recentes. In: CARDOSO, R. (Org.). A aventura antropológica: teoria e pesquisa. Rio de Janeiro: Paz e Terra, 1986.

${ }^{5}$ CHARTIER, R. A História Cultural: entre práticas e representações. Lisboa: Difel :Rio de Janeiro: Bertrand Brasil, 1990, p. 17. Noutro contexto, esse autor observa que a "investigação sobre as representações supõe-nas como estando sempre colocadas num campo de concorrências e de competições cujos desafios se enunciam em termos de poder e de dominação".

${ }^{6}$ Sobre a crítica de Sinhô e D onga aos "modernismos" no samba, ver: CABRAL, S. Falando de samba e de bambas. In: H istória da música popular brasileira. Fascículo Bide, Marçal e Paulo da Portela. São Paulo: Abril Cultural, 1984.

'GOM BRICH , E.H. Arte eilusão: um estudo da psicologia da representação pictórica. 3a ed. São Paulo: Martins Fontes, 1995, p. 316.

${ }^{8}$ CABRAL, S. No tempo de Almirante: uma história do Rádio e da M PB. Rio de Janeiro: Francisco Alves, 1990, p. 41.

${ }^{9}$ Para um mapeamento musical da Vila Isabel de então, ver: MÁXIM O, J.; DIDIER, C. N oel Rosa: uma biografia. Brasília: Linha Gráfica: UnB, 1990, cap. XV.

${ }^{10}$ É interessante atentar para o fato de que Noel, moço "lá da cidade", se coloca, aí, numa posição de distanciamento da "cidade".

${ }^{11}$ Tomo emprestado deVovelle o conceito de "mediador cultural", por ele usado ao se referir aos desafios que perpassam as relações entre "cultura de elite" e "cultura popular". Sobre os "intermediários culturais", ver: VOVELLE, M . I deologias ementalidades. 2. ed. São Paulo: Brasiliense, 1991, pp. 207-224.

${ }^{12}$ Sobre sua inusitada experiência vivida, circulando por morros e subúrbios, ver: MÁXIM O, J.; DIDIER, C. O p. cit., cap. XVI.

${ }^{13}$ Inflexões diferenciadas transparecem também no "samba carioca", que não pode ser encarado como uma forma que uniformiza todos os seus produtos. Não admitir isso seria desconhecer que o samba comporta várias vertentes.

${ }^{14} \mathrm{As}$ tensões entre "cidade" e morro persistiam, todavia. Em Sambista da Cinelândia se conclamava o sambista de morro a descer até a "cidade" e se anunciava o fim da oposição entre eles. Já em Cabaré no morro, de 1937, com a mesma Carmen M iranda, o compositor branco Herivelto M artins narra a história de uma persona- 
gem nascida no morro, criada na orgia e que rompe com a malandragem ao se dar conta de que "essa gente não tem civilização".

${ }^{15}$ Para essas e outras observações da mesma natureza, foi extremamente importante a análise do material coligido por: SANTOS, A. et. al. Discografia brasileira 78 rpm. 1902/1964. Rio de Janeiro: Funarte, 1982, vs. 1, 2 e 3.

${ }^{16}$ Para uma visão mais detalhada sobre o advento da música americana no Brasil, ver: TINH ORÃO, J. R. H istória social da música popular brasileira. São Paulo: Ed. 34, 1998, pp. 247-259.

${ }^{17}$ M ÁXIM O, J.; DIDIER, C. O p. cit., p. 242.

${ }^{18}$ AN DRADE, M . de. Macunaína: o herói sem nenhum caráter. São Paulo: Círculo do Livro, s/d. (1a ed. 1928), p. 115.

${ }^{19}$ M odernismo e música popular se comunicavam, quando mais não fosse, por vias oblíquas. Como já foi salientado por: RIBEIRO, S. C. N. "M odéstia à parte, meus senhores, eu sou da Vila!": a cidade fragmentada de Noel Rosa. Estudos H istóricos, Rio de Janeiro, v. 8, n. 16, pp. 253-254, 1995, em contraposição à "estética monumental" do projeto musical modernista, "a música popular passa a se reger pela pauta da simplicidade. Quanto a este aspecto, os músicos populares, ainda que de maneira intuitiva, se mostram mais próximos do modernismo literário de 0 swald deAndrade, M ário deAndrade e de M anuel Bandeira, do queVilla-Lobos, a maior expressão do modernismo musical".

${ }^{20}$ CABRAL, S. Pixinguinha: vida eobra. 2. 를. ed. Rio de aneiro: Lumiar, 1997, pp.137139.

${ }^{21}$ O samba era líder não só em número de gravações como em aceitação popular. Sobre os sucessos desse período, ver: SEVERIANO, J.; M ELLO, Z. H. de. A canção no tempo: 85 anos de músicas brasileiras (v. 1: 1901-1957). São Paulo: Ed. 34, 1997, 3a parte.

${ }^{22}$ MÁXIM O, J.; DIDIER, C. Op. cit.

${ }^{23}$ SANT'AN NA, A. R. de. As origens do samba, Noel Rosa e o modernismo. In: . M úsica popular emoderna poesia brasileira. 3.a ed. Petrópolis: Vozes, 1986.

${ }^{24} \mathrm{~A}$ relação visceral que uniu, historicamente, 0 samba à malandragem está exposta em diversos trabalhos. Ver, dentre outros, VASCON CELOS, G.; SUZUKI J R., M . A malandragem e a formação da música popular brasileira. In: FAUSTO, B. (Dir.). História geral da civilização brasileira - III - O Brasil republicano: economia e cultura - 1930/1964. São Paulo: Difel, 1984, eSALVAD ORI, M . A. B. Capoeiras e malandros: pedaços de uma sonora tradição popular (1890-1950). Campinas, 1990. Dissertação (M estrado em História) - Instituto de Filosofia e Ciências Humanas, Unicamp, cap. III. I mporta destacar que, lado a lado com a repressão, havia também a valorização e/ou assi milação de práticas culturais das classes populares por uma parcela de membros das elites intelectuais e das classes dominantes. Este é, 
por sinal, o fio condutor do livro de VIANNA, H . 0 mistério do samba. 2. ed. Rio de Janeiro, Jorge Zahar: UFRJ, 1995. p. 34, no qual o autor mostra por que "a transformação do samba em música nacional não foi um acontecimento repentino, indo da repressão à louvação em menos de uma década, mas sim o coroamento de uma tradição secular de contatos (...) entre vários grupos sociais na tentativa de inventar a identidade e a cultura popular brasileiras".

${ }^{25}$ FREYRE, G. Casa-grande \& senzala: formação da família brasileira sob o regime de economia patriarcal. Rio de Janeiro: José Olympio, 1933.

${ }^{26}$ Ao retomar a discussão sobre o assunto, SCHWARCZ, L. M . Complexo de ZéCarioca: notas sobre uma identidade mestiça e malandra. Revista Brasileira deCiências Sociais, São Paulo, n. 29, p. 54, out. 1995, ressalta que no Brasil, "sobretudo a partir do final dos anos 20, os modelos raciais de análise começam a passar por uma severa crítica, à semelhança do que já acontecera em outros contextos intelectuais". E lembra a decisiva contribuição da escola culturalista norte-americana, principalmente de Franz Boas, na implosão dos equívocos do determinismo racial.

${ }^{27}$ Sobre a ideologia de Estado em movimento, durante o "Estado Novo", ver: PARAN HOS, A. 0 roubo da fala: origens da ideologia do trabalhismo no Brasil. São Paulo: Boitempo, 1999, cap. I.

${ }^{28}$ RICARD O, C. M archa para O este. Rio de Janeiro: José Olympio, 1940, pp. 501 e 500.

${ }^{29}$ APU D: CABRAL, S. A M PB na era do rádio. São Paulo: Moderna, 1996, p. 55.

${ }^{30}$ Essa polêmica é reproduzida em CABRAL,S. Op. cit., pp. 70-72.

${ }^{31}$ ALM IRANTE. No tempo de N oel Rosa. 2.a ed. Rio de Janeiro: Francisco Alves, 1977, p. 146

${ }^{32}$ Apud: CABRAL, S. No tempo de Almirante: uma história do Rádio e da M PB. Rio de Janeiro: Francisco Alves, 1990, p. 118.

${ }^{33}$ Quanto à atitude de Noel Rosa diante dessa composição de Wilson Batista, ver as interpretações de: M ÁXIM O, J.; DIDIER, C. O p. cit., p. 291-292, e PARANH OS, A. $O$ Brasil dá samba?: os sambistas e a invenção do samba como "coisa nossa". In: TORRES, R. (Org.). M úsica popular en América Latina. Santiago de Chile: Rodrigo Torres, 1999, pp. 212-213, que vão de encontro às análises correntes.

${ }^{34}$ VIANNA, H. Op. cit., p.130.

${ }^{35}$ Sobre a greve que tirou do ar, em julho de 1933, as cinco emissoras cariocas, ver: CABRAL, S. No tempo deAlmirante, pp. 115-116.

${ }^{36}$ WISN IK, J. M. G etúlio da Paixão Cearense: Villa-Lobos e o Estado Novo. In: SQUEFF, E.; WISNIK, J. M . 0 nacional e o popular na cultura brasileira - música. 2ae ed. São Paulo: Brasiliense, 1983, pp. 178-190 e CONTIER, A. D. Brasil novo. M ú- 
sica, nação e modernidade: os anos 20 e 30. São Paulo, 1988. Tese (Livre-docência em História) - Faculdade de Filosofia, Letras e Ciências Humanas, USP, cap. III.

${ }^{37}$ CAM POS, F. 0 Estado Nacional: sua estrutura - seu conteúdo ideológico. Rio de Janeiro: José Olympio, 1940, p. 62.,

${ }^{38}$ TINHORÃO, J. R. Op. cit., p. 296.

${ }^{39}$ VIANNA, H. Op. cit., p. 151.

${ }^{40}$ CABRAL, S. "Falando de samba e de bambas". In: História da música popular brasileira. Fascículo Bide, M arçal e Paulo da Portela. São Paulo: Abril Cultural, 1984, p. 2.

${ }^{41}$ PARANH OS, A. Novas bossas e velhos argumentos: tradição e contemporaneidade na M PB. U berlândia, H istória \& Perspectivas, n. 3, jul./dez. 1990.

${ }^{42}$ PARANHOS, A. Vozes dissonantes sob um regime de ordem-unida: música etrabalho no "Estado N ovo". U berlândia, ArtCultura, v. 4, n. 4, jun. 2002.

${ }^{43}$ CONTIER, A. D. Op. cit., pp. 300-312.

${ }^{44}$ Cultura Política, editada pelo DIP entre 1941 e 1945, acolhia sistematicamente em suas seções textos sobre música e radiodifusão.

${ }^{45}$ Está longe de ser mera coincidência sua redescoberta, várias décadas depois, precisamente pela figura-símbolo da Bossa N ova, João Gilberto, que regravará sambas como Pra que discutir com madame, de 1945.

${ }^{46}$ Exclusivamente por razões de economia de espaço, deixo de listar aqui a discografia utilizada. Remeto os interessados na obten ção de maiores informações (datas de gravação e de lançamento, autores, intérpretes, gravadoras) sobre a quase totalidade (56) das gravações (59) mencionadas no texto à obra deSANTOS, A. et. al. 0 p. cit., vs. 2 e 3.

Artigo recebido em 03/2003. Aprovado em 05/2003. 